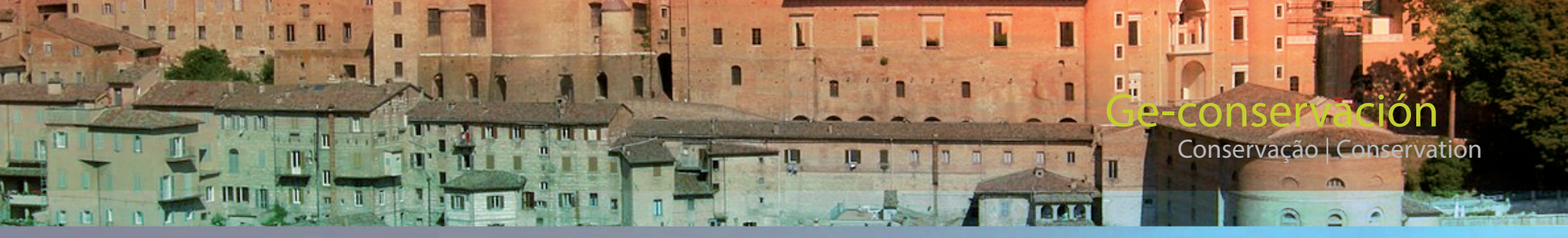

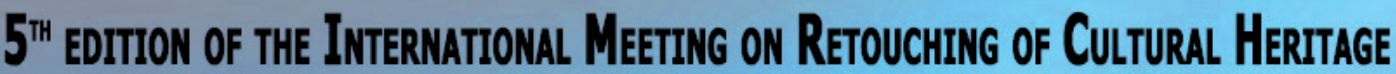

\section{The reintegration of losses in a wooden late baroque polychrome crucifix: issues and ways to approach the selection of materials}

\author{
Flavia Sorace, Marco Bacci
}

\begin{abstract}
This work will review two different interventions of plastic and pictorial reintegration that a wooden late baroque polychrome sculpture has undergone. The crucifix of Monte Giove, restored in the laboratory of the University of Urbino Carlo Bo, has unveiled large losses of the wood, some of which have altered the plastic forms and polychromy, and a shrinkage crack that has caused a deep vertical split in the torso and an alteration of the original volume. These issues have presented an opportunity for further discussion and study, relating to the potential solutions for each type of damage: the use of magnets to make the reconstructed elements movable and reversible and a filler for the wood's crack to solve both the structural and the aesthetic issues. These two choices have been discussed analysing the critical approaches, the materials selection and the aesthetic results.
\end{abstract}

Keywords: wooden sculpture, lacuna, polychromy, reintegration, reconstruction

\section{La reintegración de las pérdidas en un crucifijo baroco tardío de madera pintada: problemas y enfoques para la elección de los materiales}

Resumen: Este trabajo examinará dos intervenciones diferentes de reintegración plástica y pictórica realizadas en una escultura de madera pintada del baroco tardío. El crucifijo de Monte Giove, restaurado en el laboratorio de la Universidad de Urbino Carlo Bo, tenía pérdidas significativas de la madera que habían distorsionado las formas plásticas y la policromía, y una grieta profunda que dividía verticalmente el tórax, alterando el volumen original. Estos problemas han ofrecido la oportunidad de discutir y estudiar las posibles soluciones de cada degradación: se ha experimentado el uso de los magnetos para hacer los elementos reconstruidos móviles y reversibles y se ha evaluado un material de relleno de la madera capaz de resolver tanto los problemas estructurales como los estéticos. Estas dos elecciones operativas se discuten al aclarar el enfoque crítico, la elección de los materiales y los resultados estéticos.

Palabras clave: escultura de madera, pérdida, policromía, reintegración, reconstrucción

\section{Reintegração de lacunas num crucifixo de madeira pintada do barroco tardio: questões e abordagens para a escolha de materiais}

Resumo: Este trabalho examinará duas diferentes intervenções de reintegração plástica e pictórica realizadas numa escultura em madeira pintada do barroco tardio. O crucifixo de Monte Giove, restaurado no laboratório da Universidade Urbino Carlo Bo, apresentava lacunas significativas de madeira que haviam distorcido as formas plásticas e a policromia, e uma fenda profunda que dividia verticalmente o tórax, alterando o volume original. Estes problemas possibilitaram a discussão e o estudo de possíveis soluções para cada degradação: experimentou-se o uso de ímanes para tornar os elementos reconstruídos móveis e reversíveis e avaliou-se um preenchimento de madeira capaz de resolver ambos os problemas estruturais e estéticos. Essas duas escolhas operacionais são discutidas para esclarecer a abordagem crítica, a escolha dos materiais e os resultados estéticos.

Palavras-chave: escultura em madeira, perdido, policromia, reintegração, reconstrução 


\section{Introduction}

The Crucifix of Monte Giove is a wooden polychrome sculpture (size $132 \times 115 \times 33.5 \mathrm{~cm}$ ) by an unknown artist; this late-baroque sculpture is from the hermitage of Monte Giove in Rosciano (PU) and belongs to the Eremiti Camaldolesi Congregation.

The sculpture is in hardwood (probably poplar) and it was modeled from a single full trunk, except for the edge of the loincloth and the arms, which are not the originals. The preparation layer is made up of chalk and glue and the pictorial layers are composed of the original polychrome coat and two overpaintings. The loincloth was originally gilded and the tone of the complexion was a warm light pink; the polychromy and the gold leaf completely covered the sculpture, even the areas of the back of the figure, not visible because of the cross.

The Crucifix, as a devotional object, combines many different maintenance actions carried out over the years, which were aimed at sustaining it both in structure and in aesthetic. The religious sculptures are usually supposed to offer a true and complete representation of the sacred theme, in full compliance with the current style. There are many wooden polychrome sculptures whose damages have been "hidden" with repaintings and reconstructions; it used to be a common practice to entirely replace the damaged parts, even by changing the original subject and composition.
The Crucifix, restored in the laboratory of the University of Urbino [Figure 1], has unveiled a serious degradation of its materials. The wooden support has revealed a severe attack by xylophagous insects that have caused deep tunnels and exit holes in the wood.

The wooden support had several small lacunae coincident with the nose, the toes and the folds of the drapery: in some of these, the wood has collapsed as a result of the wood worms. There were also two missing pieces of the figure: the tip of the beard [Figure 2] and the big toe of the right foot. Along the whole length of the torso there was a shrinkage crack [Figure 3] that has caused a deep vertical split in the thorax ( $1 \mathrm{~cm}$ wide and $3,3 \mathrm{~cm}$ deep). This radial crack is common in sculptures that were not hollowed out at the back and that include the pith.

The lacunae in the pictorial layers were scattered all over the surface, particularly on the front, where a large part of the wood has been uncovered.

This paper will focus on two different solutions for the plastic and pictorial reintegration: the first on the losses of the beard and the big toe on the right foot, and the second on the deep crack in the thorax. These issues have presented an opportunity for further discussions and studies, related to the potential solutions for each type of damage, materials, methods and aesthetic results.

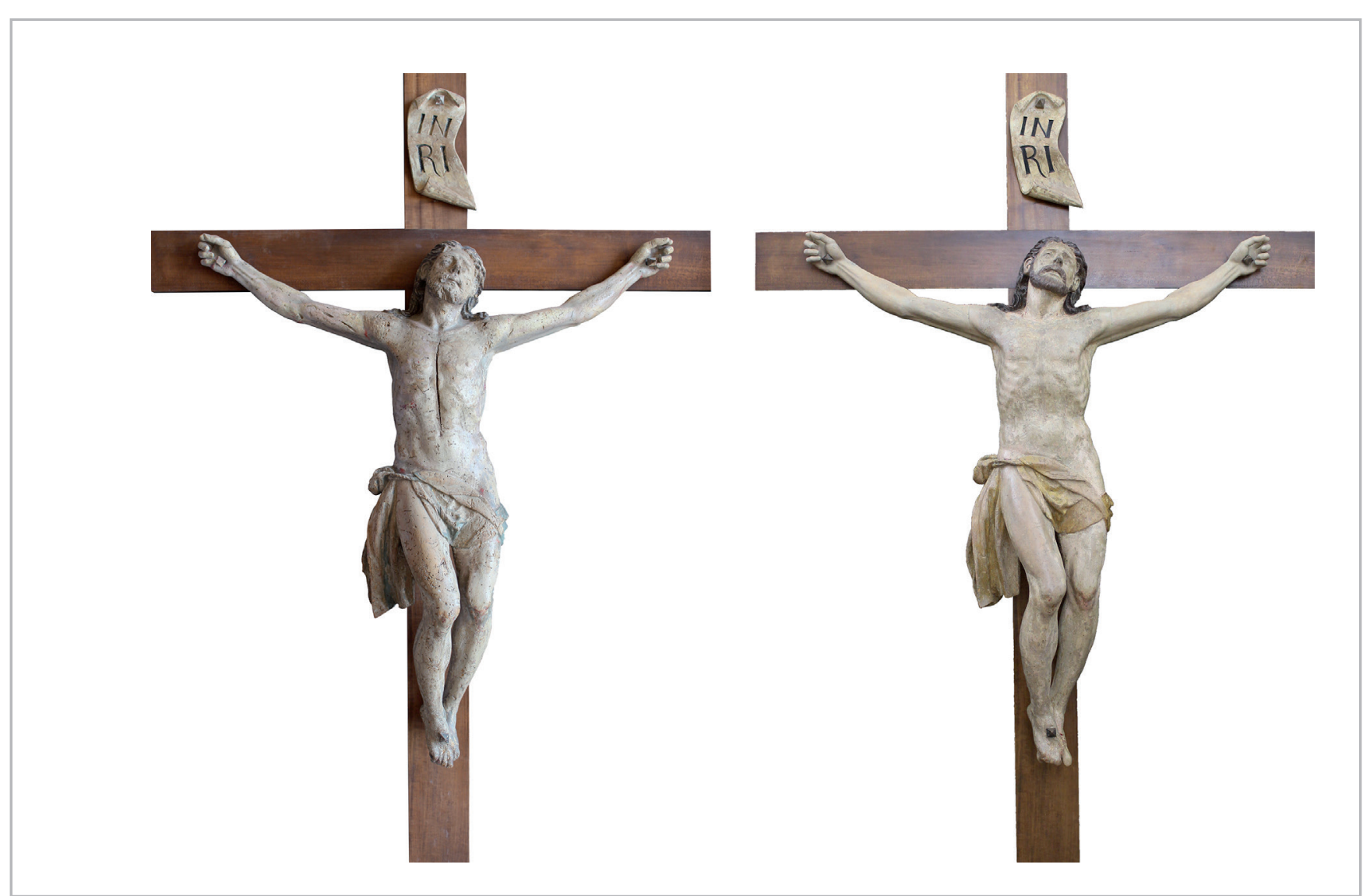

Figure 1.- The Crucifix of Monte Giove before and after the restoration. 


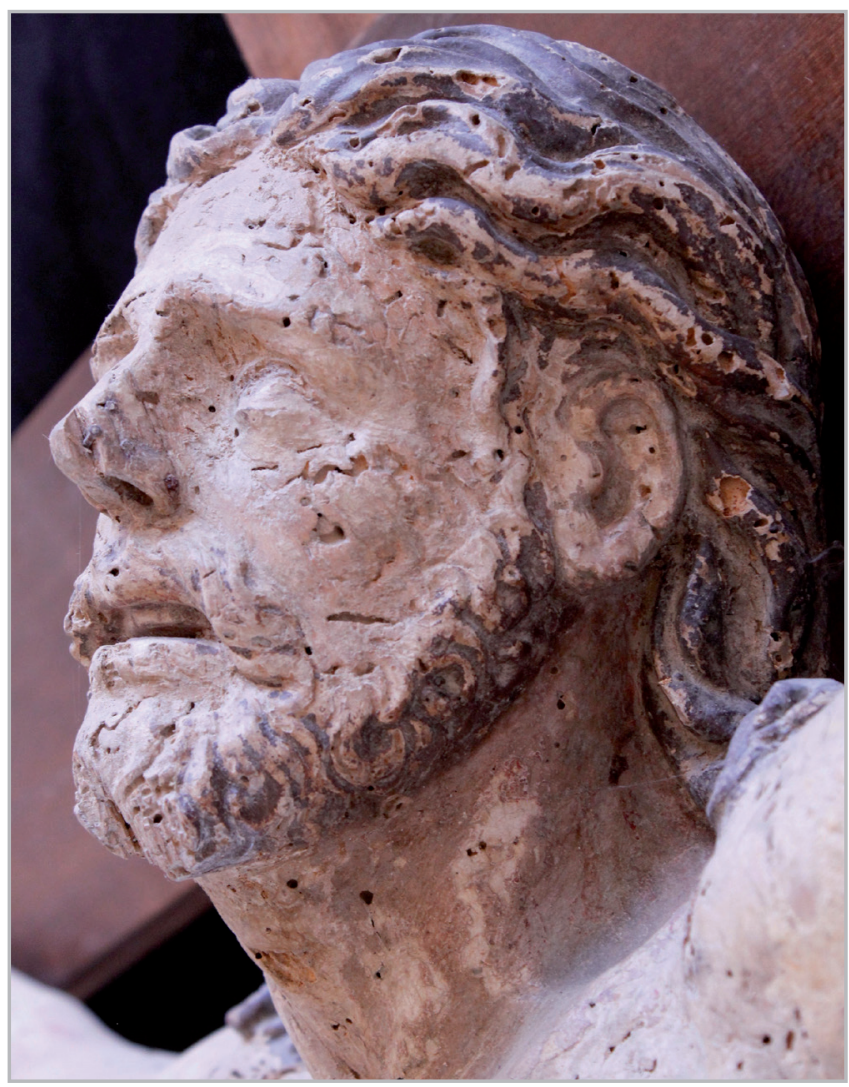

Figure 2.- Large lacuna on the beard.

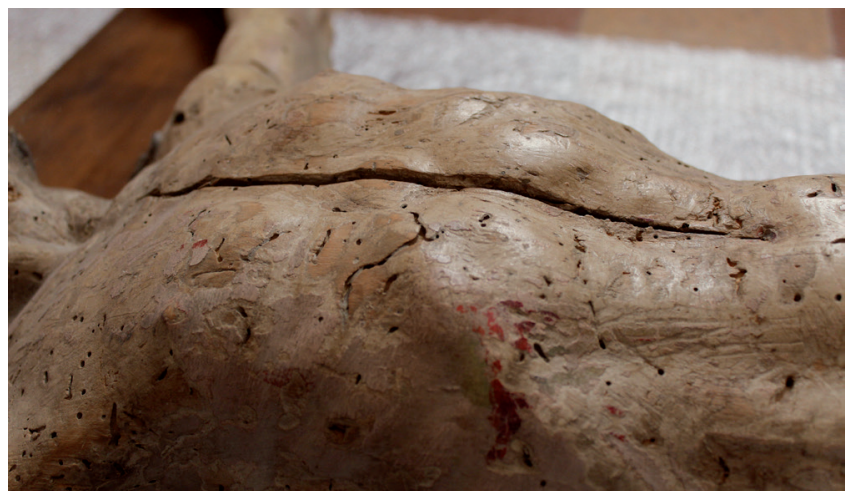

Figure 3.- Shrinkage crack in the torso.

\section{The intervention in brief}

At first, the woodworm treatment and the fixing of the paint layers that lost adhesion from the substrate, have been done. After confirming the unevenness of the overpaintings and the presence of the underlying paint layer, we have decided to remove the recent repaintings to uncover the original polychromy. The more effective method has turned out to be the combined use of oil-inwater and water-in-oil emulsions, in order to solubilize the components of the overpaintings. The residues of these layers have been mechanically removed.

Then, a new anchorage of the sculpture to the cross has been executed by using the hole in the back - probably the original anchor.
The retouching process was carried out gradually: the damages that interfered with the overall view have been taken into account (Scarzanella and Cianfanelli 1992). Firstly, the biggest tunnels and lacunae were treated with a filler made of ethanol, hydroxypropylcellulose (Klucel ${ }^{\circledR}$ G), Gesso di Bologna (calcium sulphate dihydrate) and cellulose fibers (Arbocel ${ }^{\circledR}$ BWW 40) (Casaccia et al 2014). This gel was injected deeply into the tunnels (Fasce and Borgioli 2009) and then a fine surface filler, consisting of rabbit skin glue and Gesso di Bologna, was applied. The mimetic retouching was undertaken with watercolors.

Some selected exit holes were also filled, not only because of the visual interference, but also as a conservation need, since they would increase the chance of further deposition of eggs. The fillings have been done with natural wax (coloured wax sticks), in order to completely fill the holes and tone the losses (Tonini 2015).

The large areas of the bare wood were toned down in order to harmonize them with the original polychromy. The retouching was done with color varnishes applied directly on the surface of the wood; in this way it was possible to maintain the perception of the different layers (bare wood, original gesso ground and polychromy).

The lacunae with visible wood in the gilded loincloth was not retouched, because the tonality of the wood was similar to the one of the gilded parts. The chromatic reintegration of the loincloth, was conducted only on the traces of the original ground layer surrounded by gilding.

The retouching of the gilded areas was carried out by applying small dots of pure colors (pointillism technique), using color varnishes. No gold leaf or gold coating of mica watercolor was applied below the retouching (Pannuzi et al 2028), since it was not found it necessary. As Mercier and Benati Rabelo (2018) highlight, the vibrant effect of the pointillism technique compensates the absence of the metallic brightness of the gold leaf. However some dots of mica gold pigments (AN.T.A.RES) were applied on the top (Bailao and Šustic 2013), in order to better harmonize the retouching [Figure 4].

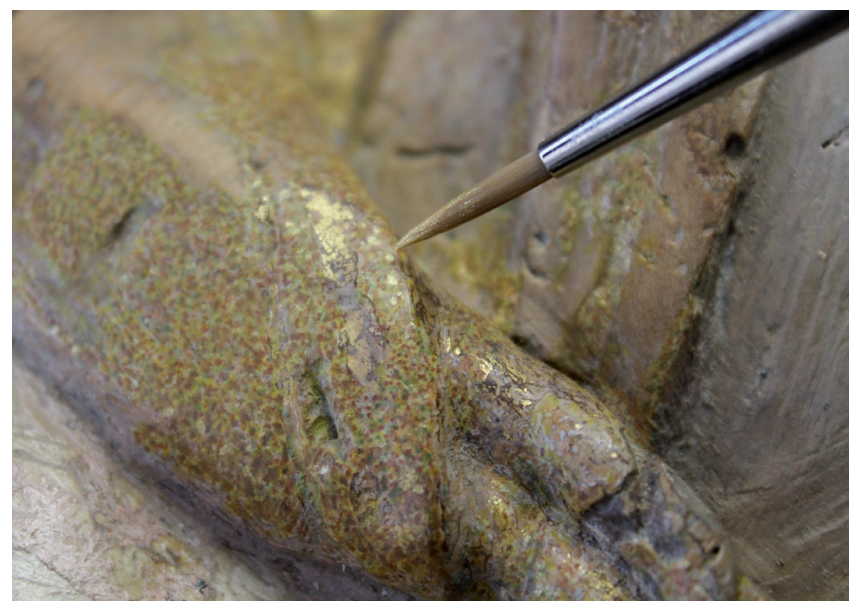

Figure 4.- Chromatic reintegration of the gilded loincloth. 


\section{Methodological approach}

\section{- The reconstruction and retouching of the missing parts}

Wooden polychrome sculptures have different methods of retouching which result from each piece specific needs and fruition. The practical decisions are the result of an exchange of ideas between the Restorer, the Client, the Chemist and the Superintendence for Cultural Heritage, whose aesthetic choices may result in very different solutions. Therefore, the different phases concerning the aesthetic proposal end up being a compromise between artistic decisions and conservation requirements.

The wood losses in the tip of the beard and in the big toe of the right foot and their reconstruction, have been discussed between the parties involved. Even though the losses had modest size, they involved the complexion's plasticity and they have been evaluated with more attention when compared to those of the loincloth.

The discussion revealed the will to focus on the legibility of the piece and to reintegrate the two major lacunae, in order to ensure aesthetic continuity, as a function of the Crucifix's liturgical purpose.

In sculpture, the plastic form contributes to the artistic expression as much as the colour (Forni 1998; Frosinini 2004); each reintegration of missing parts, in order to be correct and not represent a falsification, should result distinguishable regarding to volume and colour. These reconstructions, different in the quality of the modelling, can easily result unaesthetic and discordant from the original one. Therefore, a slight simplification of the volumes has been executed to favour the identification of the non-original parts, but not in an evident way. In fact, the carving of the beard has not been executed in detail. Furthermore, the pointillism technique has made clearly identifiable the areas where the support was not original (De Felice and Speranza 2004).

\section{— The filling of the crack}

The wood cracking is an "ambiguous lacuna" (Canocchi et al 2004), because despite appearing as an original material's loss, it isn't. It determines a morphological interruption, an alteration of the original volume and it causes a severe disorder in the overall view. It can also modify the proportions of the modelling, with different results depending on its shape, size and position.

The filling of the deep and large crack in the torso has been evaluated considering both conservation needs and aesthetics' requisites. The Crucifix's liturgical purpose led to choose the filling of the lacuna, restoring uniformity and legibility - the modest increase in volume is way less disturbing than the deep crack which, with its shade, optically emphasizes the dimensional change. Furthermore, from a conservative point of view, a crack of this kind results in a larger area that is exposed to microclimate changes and deposition of atmospheric particles. Consequently, it has been decided to fill the crack with a material that would follow the potential swelling or shrinking of the wood fibres and that could restore the regularity of volume and polychromy.

\section{Materials and methods}

\section{- The reconstructions and retouching of the missing parts}

After many tests about the shape and the perspective of the missing elements, the tip of the beard and the big toe of the right foot were moulded with an epoxy resin (Araldite ${ }^{\circledast}$ SV 427) (Borgioli and Cremonesi 2005). These elements weren't bonded to the wood, but have been made mobile with magnets. As a result, the reconstructed elements can be taken off, making the loss below visible.

The magnet strength was selected taking into account the size and weight of the elements. A small cavity was carved into the losses and on the mobile pieces, and the magnets were glued using a bicomponent extra strong epoxy resin. The reconstructed elements were then coated with a fine surface filler, consisting of rabbit skin glue and Gesso di Bologna; once dry, the filler was moulded with a scalpel and sandpaper [Figure 5].

In order to better distinguish the mobile elements, the white surface was retouched with the pointillism technique using colour varnishes [Figure 6]. This technique is especially suitable for three-dimensional objects, forming a neutral motif that doesn't enter into competition with the form (Mercier and Benati Rabelo 2018).
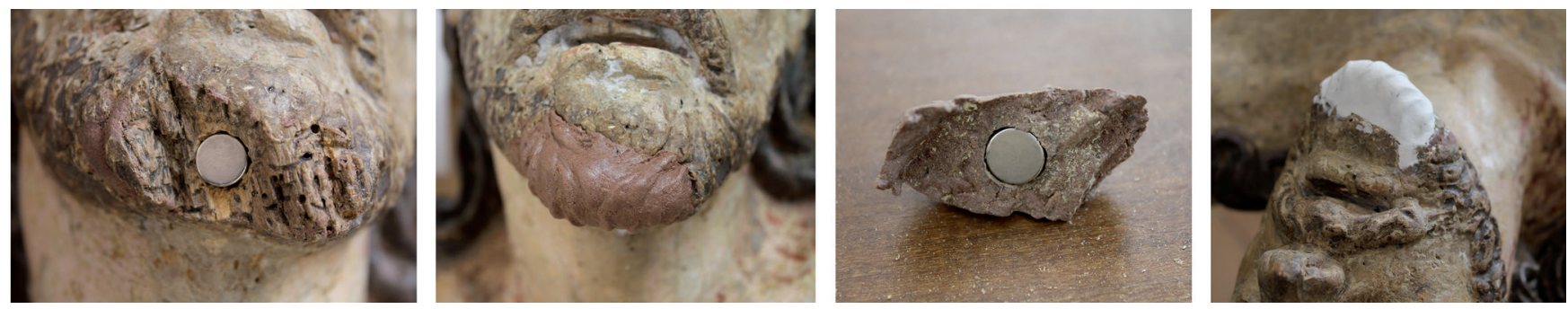

Figure 5.-Reconstruction of the tip of the beard with the application of magnets. 

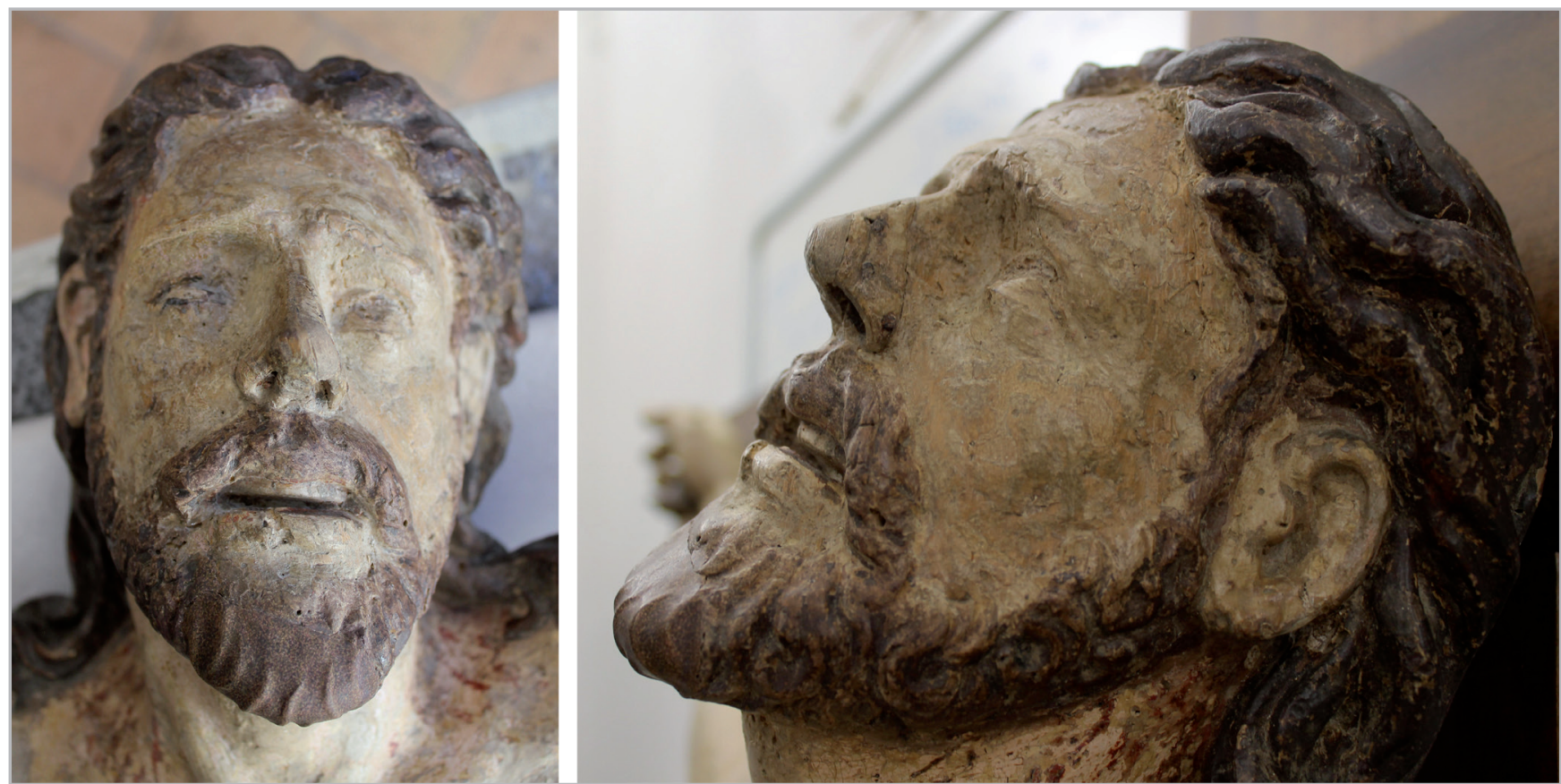

Figure 6.-The pointillism technique of retouching on the mobile element.

\section{— The filling and retouching of the crack}

In order to restore the deep crack dividing the torso, the features required by the filler were evaluated: elasticity, adhesion, compressive strength, stretch resistance, longterm durability, reversibility and chemical inertness when in contact with the wood. It was also considered the mechanical resistance of the filler; if in future the wood undergoes new movements, an elastic and non-adhesive filler will move in the same way, or at least it will break off, without causing any damages to the sculpture.

It was tested a product which is usually used in the conservation of stone materials: a fluoroelastomer. It's a copolymer belonging to the group of the fluorinated resins, characterized by the partial or total substitution of hydrogen atoms with fluorine ones. This feature confers to the molecule high stability against chemical (e.g. oxidation) and physical (e.g. heat, UV radiations) agents. The carbon-fluorine bond is in fact one of the most stable. The fluoroelastomers are polymers with high molecular weight and good elastic properties, characterized by high UV stability, chemical resistance, solubility in organic slightly polar solvents, mechanical reversibility, high water repellence and non-toxicity (Borgioli 2002). Stability tests on heat (up to $100^{\circ} \mathrm{C}$ ) and UV radiations showed no chromatic or compositional variations (Amoroso and Camaiti 1997).

The main uses of this product in the field of conservation are: binder for elastic fillings between materials with different expansion coefficients; water and oil repellent; surface binder for absorbent stone and antigraffiti protective coat for stone surfaces (Camaiti et al 1991; Moggi et al 2004).
It was decided to test this material - widely used in stone conservation - on wood, as an alternative to fillers based on epoxy resins.

Tests on the dilution of the product, types of inert substances, ratios and application methods were carried out. It's possible to find commercial products (e.g. Fluoline ${ }^{\oplus S T}$, Idrofluoro ${ }^{\circledR} 10$ ) that are already diluted however, it was chosen the pure fluoroelastomers in plates (AN.T.A.RES), by diluting it in acetone with different percentages. As an alternative to acetone, with which they are formulated, butyl acetate and ethyl acetate - with low toxicity - can be used.

The cellulose fibers (Arbocel ${ }^{\oplus} \mathrm{BWW} 40$ ), naturally akin to the wood, were chosen as an inert; in addition to different polymeric materials, these can improve the forming properties and reduce the shrinking after drying (Cavaleri et al 2017; Megna et al 2006).

The tests have revealed that the best solution is a $10 \%$ mixture of fluorelastomers in acetone, while the best inert are cellulose fibers and wood powder in a ratio of 6 to 4 . The weight ratio between the amount of the inert and the diluted resin is 1 to 5 . After many colour tests, the best mixture of powder pigments (Raw Umber, Ivory Black and Green Earth) has been selected to adjust the tone of the compound.

After consideration of the positive outcome of these tests, it was decided to use this compound to fill the shrinkage crack. The mixture was applied in three phases: first, it was injected without the inert, to help the filler adhere to the porous wood; then the cavity was filled with the fluoroelastomer and the inert; once dry, the filling of 

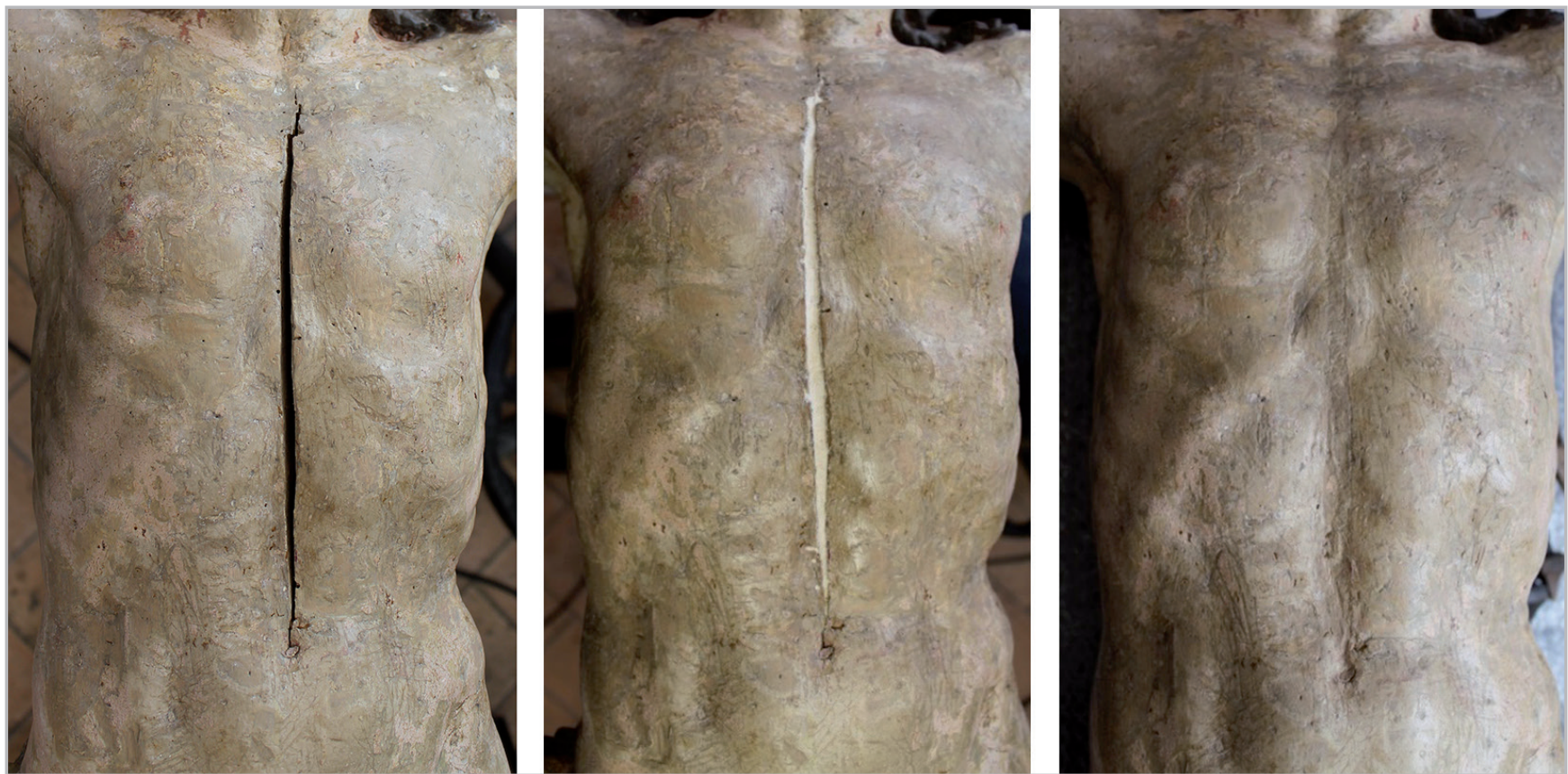

Figure 7.-Steps of the filling on the torso crack.

the crack was completed by adding pigments to the compound [Figure 7]. After drying, the surface was dabbed with acetone in order to remove residues of the elastomer from the top layer that would facilitate the laying of dust (Amoroso and Camaiti 1997).

\section{Results}

\section{- The reconstruction and retouching of the missing parts}

The use of magnets ensured the complete reversibility of the intervention with a low impact on the sculpture, avoiding resin reconstructions in contact with the wood. The mobile elements can be easily removed if in the future they are no longer required or if the sculpture undergo further conservation treatments.

The pointillism retouching technique, selected for the mobile elements, has made possible to restore the legibility of the polychromy, in accordance with the criterion of distinctiveness of the reintegration.

\section{- The filling and retouching of the crack}

The positive outcome of the reintegration with the fluoroelastomer, has allowed to introduce a new binder for fillings on wooden supports, on which it will be possible to do new specific studies.

The filler with the fluoroelastomer, inert and pigmentsbased mixture has avoided the use of a fine surface filler and a pictorial coat. The surface roughness and the uneven colour of the filler perfectly match with the surrounding area, which is almost entirely scratched wood.
The problems related to the wooden structure and its natural movements have been solved in a single operation. Due to the characteristics of the selected product and the modifications made to the mixture, it has been also possible to improve the perception of the image.

\section{Conclusions}

No intervention method is obvious: each conservation issue or damage has several solutions regarding methodologies and materials. In this case, many materials and methods could be used for the reconstruction of the losses and for the filling of the crack. The choice on the application of magnets and the use of fluoroelastomers, have been made in order to test new materials and methods concerning reversible reconstructions and the filling of deep cracks.

The criterion of reversibility is frequently taken for granted and rarely the intervention methods are truly reversible. Our purpose was to carry out operations with the least impact on the original materials, which were already damaged and altered by previous restorations. Therefore, the reconstructions of the missing parts, bonded by the magnets, can be easily removed allowing the damaged areas to be visible again. The filling with the fluoroelastomer is also completely reversible - the material can be easily mechanically removed or dissolved in organic solvents.

At the same time, it was taken into account the subjectivity of the reconstruction of the missing parts, of which there were no information or photographic documentation. The structural continuity of shape and color were restored, without overdoing it. 
The restoration of the Crucifix gave back to the religious community of Monte Giove one of the main art works of the hermitage, by ensuring the physical preservation of the sculpture as well as a better legibility of its image. Significant results have been obtained and many reflections and suggestions came out for further researches and studies about these practical solutions.

\section{References}

AMOROSO, G. G., CAMAITI, M. (1997). Scienza dei materiali e restauro. La pietra: dalle mani degli artisti e degli scalpellini a quelle dei chimici macromolecolari. Alinea (collana Manuali), Firenze, 177-197.

BAILAO, A., ŠUSTIC, S. (2013). "Retouching with mica pigments", E-conservation Journal, 1: 45-60.

BORGIOLI, L., CREMONESI, P. (2005). Le resine sintetiche usate nel trattamento di opere policrome. Padova: II Prato (collana I talenti). BORGIOLI, L. (2002). Polimeri di sintesi per la conservazione della pietra. Padova: II Prato (collana I talenti), 66-84.

CAMAITI, M., INGOGLIA, R., MOGGI, G., PASETTI, A., SCALA, A., BISCONTIN, G., MIETTO D. (1991). "Controllo della reversibilità di trattamenti protettivi effettuati con polimeri fluorurati su materiali lapidei". In Le pietre nell'architettura: struttura e superfici: Atti del convegno di studi, Bressanone, 25-28 giugno 1991, Padova: Libreria Progetto Editore, 267-76.

CANOCCHI, G., GIGLI, M. C., MAZZONI, M. D., STIBERC, P. (2004). "La lacuna nella scultura lignea. Problematiche di intervento". In LACUNA. Riflessioni sulle esperienze dell'Opificio delle Pietre Dure. Atti dei convegni, Ferrara 7 Aprile 2002 e 5 Aprile 2003, Firenze: Edifir, 131-135.

CASACCIA, A., CORSINI, I., MINOTTI, D. (2014). Ricerca ed applicazione di un nuovo riempitivo per il supporto ligneo dell'Ultima Cena di Giorgio Vasari. OPD Restauro, Firenze: Centro Di, 26: 120-129.

CAVALERI, T., GATTI, A., MARELLI, I., APPI, E., BOZZATO, S., GASTALDELLI, F., SANNA N. (2017). "L'uso della polpa di cellulosa come riempitivo di profondità per il risarcimento delle mancanze di materia lignea: il caso studio di un'inedita copia da Ribeira della collezione Lodovico Pogliaghi di Varese". In Lo Stato dell'Arte 15: XV Congresso Nazionale IGIIC, Volume degli atti, Università degli Studi di Bari Aldo Moro, 12-14 ottobre 2017, Firenze: Nardini Editore, 435-444.

DE FELICE, R. C., SPERANZA, L. (2004). San Bernardino. OPD Restauro, Firenze: Centro Di, 16: 232-236.

FASCE, M., BORGIOLI, L. (2009). "Metodologia di iniezione di stucchi in opere lignee policrome". In Lo stato dell'arte 7: VII Congresso nazionale IGIIC, Volume degli Atti, Napoli, Castel dell'Ovo, 8-10 ottobre 2009, Firenze: Nardini Editore, 451456.
FORNI, V. (1998). II problema critico delle integrazioni plastiche nella scultura lignea policroma. OPD Restauro, Firenze: Centro Di, 10: 95-111.

FROSININI, C. (2004). “La lacuna nel progetto di restauro oggi”. In LACUNA. Riflessioni sulle esperienze dell'Opificio delle Pietre Dure. Atti dei convegni, Ferrara 7 Aprile 2002 e 5 Aprile 2003, Firenze: Edifir.

MEGNA, B., PARLAPIANO, M., ROMANO, L., PIZZO, B., RIZZO, G. (2006). "L'uso delle cariche cellulosiche per migliorare la compatibilità col legno dei materiali polimerici utilizzati nella stuccatura delle fessure". In Lo stato dell'arte 3: III Congresso nazionale IGIIC. Volume degli atti, Palermo, Palazzo Steri, 22-24 settembre 2005, Firenze: Nardini Editore, 202-207.

MERCIER, E., BENATI RABELO, E. (2018). "The golden stain of time: the inpaintings of gildings on wooden sculpture". En Postprint of the 4th International Meeting on Retouching of Cultural Heritage, RECH4, Spilt, Croatie, 20 octobre 2017, 139-151.

MOGGI, G., GUIDETTI, V., PASSETTI, A., VICINI, S. (2004). “Sistemi innovativi a base di polimeri fluorurati per la conservazione di materiali lapidei artificiali". In Architettura e materiali del Novecento: conservazione, restauro, manutenzione, Atti del convegno di studi, Bressanone, 13-16 luglio 2004, Venezia: Arcadia Ricerche.

PANNUZI, S., VALENZUELA, M., MONTEMAGGIORI, D., GALANTI, G. (2018). "Gold and Polychromy on stone: a proposal of retouching methodology that can apply on all tridimentional artworks". In Postprint of the 4th International Meeting on Retouching of Cultural Heritage, RECH4, Spilt, Croatie, 20 octobre 2017, 138-143

ROSSI SCARZANELLA, C., CIANFANELLI, T. (1992). “La percezione visiva nel restauro dei dipinti. L'intervento pittorico". In Problemi di restauro. Riflessioni e ricerche, Firenze: Edifir, 185-211.

TONINI, F. (2015). La scultura lignea, tecniche e restauro. Manuale per allievi restauratori. Padova: II Prato (collana Lineamenti di restauro e conservazione dei beni culturali).

\section{Author/s}

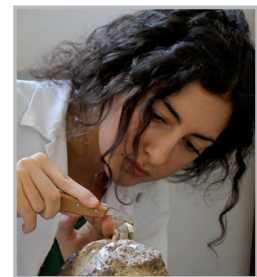

\section{Flavia Sorace}

flavia2295@hotmail.it

University of Urbino Carlo Bo - Department of Pure and Applied Sciences, Conservation and Restoration of Cultural Heritage, Urbino (PU), Italy.

Flavia graduated as restorer and conservator of cultural heritage at the Carlo Bo University of Urbino with a specialization in "Paintings on wooden and textile support, wooden structures and sculptures and synthetic materials". Her practical thesis concerned the restoration of the wooden polychrome Crucifix from the hermitage of Monte Giove. 


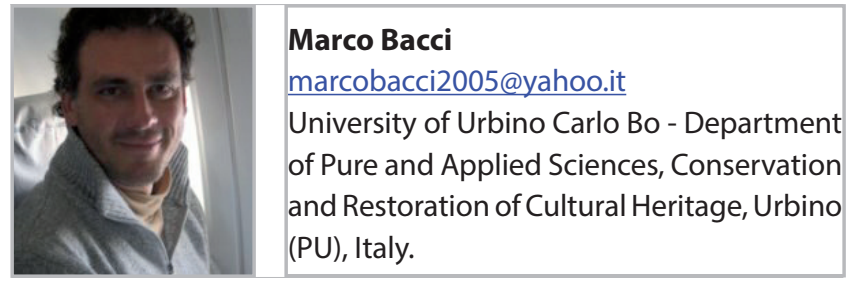

Marco is a restorer and professor at the School of Conservation and Restoration, University of Urbino and at the Academy of Fine Arts Aldo Galli in Como. He collaborates with materials analysis laboratory (LAM) at the University of Florence. He has worked as a restorer in the Uffizi Museum of Florence, in the University of Naples and in Syria and Palestine for UNESCO. He participates in the Heritage First Aid project (HEFA) with the University of Urbino. Author of scientific works.

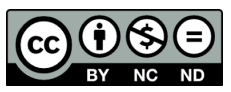

https://doi.org/10.37558/gec.v18i1.823 